\title{
Are Mikvehs Responsible for GBS Carriers among Orthodox Jewish Women?-A Prospective Observational Study
}

\author{
Jacky Herzlich1,2,3, Daniel Lubin ${ }^{1,3}$, Yehudit Schindler ${ }^{1,4}$, Osnat Wittmann ${ }^{2,3}$, Ronella Marom ${ }^{2,3^{*}}$ \\ ${ }^{1}$ Departments of Neonatology, Mahayanei Hayeshua Center, Bney Brak, Israel \\ ${ }^{2}$ Departments of Neonatology, Lis Maternity Hospital, Tel Aviv Sourasky Medical Center, Tel Aviv, Israel \\ ${ }^{3}$ Sackler Faculty of Medicine, Tel Aviv University, Tel Aviv, Israel \\ ${ }^{4}$ Departments of Microbiology, Mahayanei Hayeshua Center, Bney Brak, Israel \\ Email: *marom.ronella@gmail.com
}

How to cite this paper: Herzlich, J., Lubin, D., Schindler, Y., Wittmann, O. and Marom, R. (2020) Are Mikvehs Responsible for GBS Carriers among Orthodox Jewish Women?-A Prospective Observational Study. Open Journal of Obstetrics and Gynecology, 10, 909-913.

https://doi.org/10.4236/ojog.2020.1070086

Received: June 16, 2020

Accepted: July 17, 2020

Published: July 20, 2020

Copyright $\odot 2020$ by author(s) and Scientific Research Publishing Inc. This work is licensed under the Creative Commons Attribution International License (CC BY 4.0).

http://creativecommons.org/licenses/by/4.0/

\begin{abstract}
Background: Maternal colonization with group B streptococcus (GBS) is an important risk factor for neonatal sepsis. A "mikveh" is a pool of water for ritual immersion by Jewish women. It had been reported to be a risk factor for GBS colonization. Objective: To determine whether there is an association between ritual immersion in the mikveh pools and GBS carriership. Methods: Water samples and bacterial swabs were taken from eight mikveh pools centers at two separate occasions and tested for GBS growth. For determination of the total number of live, aerobic bacteria, each sample was grown on strep selective agar for 48 hours at $37^{\circ} \mathrm{C}$ and $\mathrm{CO}_{2} 5 \%$. Results: All the samples were tested. No trace of GBS was found in any of the samples. Conclusions: The findings of this study refute earlier findings and suggest that there is no association between ritual immersion in mikvehs and GBS carriership.
\end{abstract}

\section{Keywords}

Group B Streptococcus Carrier, Mikveh, Colonization, Religiosity, Early on Set Sepsis

\section{Introduction}

Invasive group B streptococcal (GBS) disease plays an important role in infectious illness and death during the first week of life. Clinical trials in the 1980s showed that early-onset GBS infection and disease were significantly decreased 
by administering prophylactic antibiotics intrapartum to women who were colonized with GBS [1] [2] [3] [4]. Women who are identified as being GBS-colonized through culture-based screening are 25 times more likely to deliver an infant with early-onset infection than women with negative prenatal cultures [5]. Identification of maternal colonization through universal, culture-based screening with the recommendation of providing intrapartum antibiotic prophylaxis (IAP) for women with positive screening results has been recommended since 2002 [6]. This strategy is endorsed by the American Academy of Pediatrics, and it has been widely adopted in the United States, resulting in an estimated $80 \%$ decrease in early-onset GBS infection [7].

In Israel, the official policy of the Ministry of Health since 2005 has been to avoid general screening in pregnant women for GBS colonization between gestation weeks 35 - 37 because of the low incidence of early-onset sepsis (EOS) due to GBS in neonates [8]. There has, however, been a gradual increase in the incidence of GBS carriership in Israel during the past few years [9] leading to a search for its source.

A mikveh is a pool of water used by both men and women for the purpose of ritual immersion for purification after a thorough cleansing of the entire body. Non-pregnant orthodox Jewish women attend a mikveh each month approximately for 14 days since the onset of menses. In 2015, Drai-Hasid et al. reported that immersion in a mikveh pool is a risk factor for GBS colonization [10]. We questioned the validity of that claim since the chloride used to sanitize the water in mikveh pools is the same as that used in swimming pools. This study was designed to determine whether there is any association between immersion in the water of mikveh pools and GBS carriership.

\section{Materials and Methods}

A total of sixteen water samples were collected manually straight from the pool in sterile well-labeled $100 \mathrm{ml}$ bottles and a total of sixteen surface swabs were collected by friction and scratching the pool's walls surface manually. The samples were purposively collected twice on different Sundays from eight different mikveh pools located in one city in the center of Israel that has a large population of ultra-Orthodox Jews. The pools were filled with fresh water on Thursdays and it was not replaced until Sunday. An average of 100 women attend each evening, which means that around 300 women had used the mikveh by the Sunday morning we examined the water. The water samples were collected in morning before a pool routine cleaning according to standard methods for the examination of water and wastewater [11], transported at $4^{\circ} \mathrm{C}$ within 1 hour from the collection time, using appropriately insulated coolers, to the outsourcing microbiology laboratory accredited for performing a water testing.

The surface swabs were collected from the pools walls by sterile transport swabs (Transwab ${ }^{\circledast}$ Amies. Copan) and were transferred to Mahayanei Hayeshua microbiology laboratory for further investigation. 


\section{Laboratory Analysis}

\section{Total Aerobic Plate Count}

Membrane filtration technique was employed to determine a Total count of viable GBS in accordance with Israeli Ministry of Health guidelines, State of Israel American Public Health Association (APHA), 9222D and 9260F.

For each test the $100 \mathrm{ml}$ of the pool water sample was aseptically filtrated. The filters were placed on plate count agar (PCA) and grown for 3 days at $37^{\circ} \mathrm{C}$ to determine the total number of live, aerobic bacteria. The number of bacteria is expressed as colony-forming units per $\mathrm{ml}(\mathrm{CFU} / \mathrm{ml})$.

\section{Isolation of GBS}

For GBS detection the filters and the surface swabs were cultured on selective media (Strep selective agar; Hy-labs) and incubated for 48 hours at $37^{\circ} \mathrm{C}$ with $5 \% \mathrm{CO}_{2}$. From each Strep selective agar plate a suspected colonies were isolated, Gram stained using AerosprayWescor, Slide stainer Cytocentrifuge and observed with a light microscope (Olympus BX43, USA). Identification of GBS was performed by classical/biochemical methods according to the literature [12] [13] and using the VITEK $^{\oplus}$ MS (bioMerieux, France) system. The study protocol was approved by the Mahayanei Hayeshua Medical Organization Institutional Review Board.

\section{Results}

Eight different mikvhes pools in two different time points in a lag of a week were sampled. All samples were taken manually by the same person; the principle investigator $(\mathrm{JH})$. Sixteen containers with $100 \mathrm{ml}$ of water in each were prospectively taken from the pool, total of $1600 \mathrm{ml}$ of pool water for laboratory testing. Also sixteen bacterial swabs were taken and scratched from the pools walls and were cultured for growth of GBS. In none of the water samples nor the pools wall bacterial swabs GBS was detected or isolated, and all cultures were determined as being negative for GBS.

\section{Discussion}

To the best of our knowledge, this is the first prospective study that evaluated the incidence of GBS in water samples and from swabs from Mikvehs' walls. There has been a constant increase in the prevalence of group B streptococcus carrier status in Israel, from around 3\% in the 1980s reaching up to $17 \%$ in 2010 [8], and continuing to rise to $22 \%$ from 2010 to 2016 [7]. In contrast to the large increase in the prevalence of GBS carriers, the prevalence of early-onset sepsis (EOS) due to GBS among the babies born to mothers with a risk factors for EOS decreased from $0.71 / 1000$ births to $0.52 / 1000$ births, and from $0.33 / 1000$ births to $0.18 / 1000$ births in 2016 among the babies without a maternal risk factor for EOS [7]. Concerns about a correlation between the increase in GBS carriers and maternal ritual bathing in mikvehs have risen since Drai-Hasid et al.'s publication [10]. In contrast to the former study by Drai-Hasid et al., who suggested an 
association between ritual immersion in Mikvehs and GBS carriership according to a cross-sectional survey from 436 parturient Jewish women from Jerusalem, we in a prospective manner, tested cultures for GBS in the Mikvehs and not the GBS status of the mothers. Our systematic search of the published literature in PUBMED failed to yield any other report on this issue. Although the numbers of sampling were small (the Religiousness and holiness of the places prevented us from taking more samples in different time points) the strength of the study was the prospective methods which the data were collected.

\section{Conclusion}

The results of our current investigation raise the possibility that there is no association between ritual immersions in mikvehs to GBS carriers among the women who attended them. The routine use of a chloride substance for sanitizing the mikveh pools is probably responsible for the eradication of GBS.

\section{Acknowledgements}

We acknowledge Esther Eshkol, MA, whom provided assistance in preparing and editing the manuscript.

\section{Conflicts of Interest}

The authors declare no conflicts of interest regarding the publication of this paper.

\section{References}

[1] Centers for Disease Control and Prevention (1996) Prevention of Perinatal Group B Streptococcal Disease: A Public Health Perspective. MMWR Recommendations and Reports, 45, 1-24.

[2] Verani, J.R., Mccee, L. and Schrag, S.J. (2010) Prevention of Perinatal Group B Streptococcal Disease-Revised Guidelines from CDC. MMWR Recommendations and Reports, 59, 1-32.

[3] The Centers for Disease Control (2002) Revision of Guidelines for the Prevention of Perinatal Group B Streptococcal Disease. JAMA, 287, 1106-1107. https://doi.org/10.1001/jama.287.9.1106-JWR0306-2-1

[4] Russell, N.J., Seale, A.C., O'Sullivan, C., et al. (2017) Risk of Early-Onset Neonatal Group B Streptococcal Disease with Maternal Colonization Worldwide: Systematic Review and Meta-Analyses. Clinical Infectious Diseases, 65, S152-S159. https://doi.org/10.1093/cid/cix655

[5] Boyer, K.M. and Gotoff, S.P. (1985) Strategies for Chemoprophylaxis of GBS Early-Onset Infections. Antibiot Chemother, 35, 267-280. https://doi.org/10.1159/000410380

[6] Schrag, S., Gorwitz, R., Fultz-Butts, K. and Schuchat, A. (2002) Prevention of Perinatal Group B Streptococcal Disease. Revised Guidelines from CDC. MMWR Recommendations and Reports, 51, 1-22.

[7] Van Dyke, M.K., Phares, C.R., Lynfield, R., et al. (2009) Evaluation of Universal Antenatal Screening for Group B Streptococcus. The New England Journal of Medicine, 360, 2626-2636. https://doi.org/10.1056/NEJMoa0806820 
[8] MOH Official Recommendation for GBS Screening. https://www.health.gov.il/hozer/mr22_2005.pdf

[9] ICDC (Israel Center for Disease Control), Ministry of Health, Gertner Institute, Chaim Sheba Medical Center. https://www.health.gov.il/PublicationsFiles/GBS.pdf

[10] Drai-Hasid, R., Calderon-Margalit, R., Lev-Sagie, A., et al. (2015) Ritual Immersion in a Mikveh Is Associated with Increased Risk of Group Streptococcal Carrier State in Israeli Parturient Women. Open Journal of Obstetrics and Gynecology, 5, 769-774. https://doi.org/10.4236/ojog.2015.514108

[11] Rice, E.W., Baird, R.B., Eaton, A.D. and Clesceri, L.S. (1992) Standard Methods for the Examination of Water and Wastewater. 23rd Edition, American Public Health Association (APHA), Washington, D.C.

[12] Garcia, L.S. and Isenberg, H.D. (2010) Clinical Microbiology Procedures Handbook. 3rd Edition, American Society for Microbiology Press, Washington, D.C., 642-658. https://doi.org/10.1128/9781555817435

[13] Jorgensen, J.H., Pfaller, M.A., Carroll, K.C., Funke, G., Landry, M.L., Richter, S.S. and Warnock, D.W. (2011) Manual of Clinical Microbiology. American Society for Microbiology Press, Washington, D.C., 412-429 